\title{
3o. Selâhattin Enis’in öykülerinde kadın
}

\section{Yusuf ÇOPUR'}

APA: Çopur, Y. (2021). Selâhattin Enis'in öykülerinde kadın. RumeliDE Dil ve Edebiyat Araştırmaları Dergisi, (24), 562-570. DOI: 10.29000/rumelide.990155.

$\ddot{\mathbf{O} z}$

Yaşadığı dönemdeki (1892-1942) birey-toplum çatışmasını natüralist ve determinist bir anlayışla ele alan Selâhattin Enis Atabeyoğlu, öykülerinde hayatın kötülüklerini, iğrençliklerini tüm çarpıklığı ve gerçekliğiyle anlatır. Selâhattin Enis'in öykülerinde başta öfke ve nefret olmak üzere duygular çok belirgindir. Toplumun kendisi ve onun yozlaşan değerleri yazar için tüm sosyal kötülük ve ahlaksızlıkların temelini oluşturur. Selâhattin Enis toplumsal yozlaşma ve toplumun ahlaki çöküntülerini kadın karakterleri üzerinden ele alır. Yazarın öykülerindeki kadın karakterlerin çoğu kötüdür. Kadın karakterlerin neredeyse tamamı hayat kadınıdır. Selâhattin Enis’in hayat kadını olmayan kadın karakterleri ise eşini aldatan veya ailesine karşı sadakatsiz kimselerdir. Bu kapsamın dışında kalanlar da kötü bir şekilde can verirler. Yazarın kadın karakterlerini ele alış biçimi yüzeysel ve psikolojik gerçeklikten yoksun ve yazarın öykülerinde kadınlar, sadece birer figürdür. Selâhattin Enis kadınlara olan "kötü" bakış açısını öykülerindeki kadın karakterlerine yansıtır. Yazarın kadınlara karşı bu olumsuz yaklaşımı kadın karakterlerin kendi gerçekliklerinden ziyade yazarın kendi kadın gerçekliğini yansıtmasına neden olur. Selâhattin Enis’in öykülerinde kadınların fiziki tasvirlerinde en çok gözler yer alır. Gözler ve dudaklar kadınların "güzellik" nitelemesinde sık kullanılır. İncelenen öykülerde güzel kadınlar, bu güzelliklerini insanların hayatlarını mahvetmek için kullanırlar. Yazar, kadın karakterlerini, güzel kadınlara karşı nefrete varabilecek bir yaklaşımla anlatır. Yazarın incelenen öykülerinde kadın, yazarın öfke ve nefretiyle acımasızca ve sertçe toplumsal kötülük ve yozlaşmaların zeminine oturtulur.

Anahtar kelimeler: Selâhattin Enis öykü, kadın, Bataklık Çiçeği

\section{Women in the stories of Selâhattin Enis}

\begin{abstract}
Abstcrat
Selâhattin Enis Atabeyoğlu, who handles the individual-society conflict in his lifetime (1892-1942) with a naturalistic and determinist understanding, tells the evil and disgusting of life in his stories with all its twists and turns. Emotions, especially anger and hatred, are very evident in the stories of Selâhattin Enis. It is the basis of all evil and immorality for society itself and its decadent writer. Selâhattin Enis deals with social degeneration and the moral degeneration of society through female characters. Most of the female characters in the author's stories are bad. Almost all of the female characters are prostitutes. The female characters of Selâhattin Enis who are not prostitutes are people who cheat on her husband or are unfaithful to her family. The author's treatment of female characters is superficial. The handling of women in the author's stories lacks psychological reality. Women are the figures in the author's stories. Selâhattin Enis reflects his "bad" point of view on women to the female characters in his stories. The author's negative attitude towards women causes the author to reflect her own female reality, not the female characters themselves. In the stories of
\end{abstract}

Dr. MEB, Türk Dili ve Edebiyatı (İstanbul, Türkiye), copuryusuf@gmail.com, ORCID ID: 00oo-00o3-2196-5867 [Araştırma makalesi, Makale kayıt tarihi: 29.03.2021-kabul tarihi: 20.09.2021; DOI: 10.29000/rumelide.990155]

Adres | Address

RumeliDE Dil ve Edebiyat Araşturmaları Dergisi Osmanağa Mahallesi, Mürver Çiçeği Sokak, No:14/8 Kadıköy - ISTANBUL / TÜRKIYE 34714 e-posta: editor@rumelide.com

RumeliDE Journal of Language and Literature Studies Osmanağa Mahallesi, Mürver Çiçeği Sokak, No:14/8

Kadıköy - ISTANBUL / TURKEY 34714 tel: +90 $5057958124,+902167730616$

e-mail: editor@rumelide.com

phone: +90 5057958124, +90 2167730616 
Selâhattin Enis, eyes are the most common in the physical depictions of women. Eyes and lips are present in all stories in terms of "beauty" of women. In the stories analyzed, beautiful women use these beauties to ruin people's lives. In most of his stories, the author tells his characters in an approach that can lead to hatred towards beautiful women. In the stories examined by the author, the woman is ruthlessly and harshly placed on the ground of social malice and corruption with the anger and hatred of the author.

Keywords: Selâhattin Enis story, women, Bataklık Çiçeği

\section{Giriş}

Selâhattin Enis makalelerinin yanı sıra roman ve öykü türlerinde eser vermiştir. Yazarın ilk yazısı "Gurup ve Guruptan Sonra” ismini taşır ve bu yazı 1909'da Resimli İstanbul mecmuasında yayımlanır. Aynı sene yine Resimli İstanbul mecmuasında sırasıyla “İptida-i Aşk yahut Uzaklarda”, "Baykuşlar” ve "Pembeliklerde... Maviliklerde” yazıları yayımlanır. Bu yazılar mensure özelliği taşır. Yazar, Rübabçılara katılıncaya kadar Piyano, Resimli Kitap, Kadın gibi kısa ömürlü dergilerde yazılar kaleme alır. Yazar, bu yazılarda üslup bakımından Servet-i Fünuncular ve Fecr-i Âticilerin etkisindedir. 1912 yllında ilk romanı Neriman yayımlanır. Selâhattin Enis edebiyat camiasına adını Birinci Dünya Savaşının henüz başlarında yayımladığı "Bir Kadının Son Mektubu" isimli öyküsüyle duyurur. Yazar savaş dönemlerinde Safahat-ı Şïr ve Fikir mecmuasında "İsyan" isimli öyküsünü, Fağfur'daysa "Çingeneler" ve "Bağırsak" adlı öykülerini yayımlar. Enis'in bu mecmualarda birkaç mensuresi daha yayımlanır. 23 Ekim 1919'da Ahmet Tarı ile birlikte Kaplan risalesini çıkaran yazarın 1923’ün ocak ayında Zümrüdü Anka dergisinde "Erkek Kızlar” adında bir öyküsü yayımlanır. İkinci romanı Fitnat’ın Sergüzeşti, 1922 yllında İleri gazetesinde tefrika edildi, 1923’te Zaniyeler adıyla kitap olarak basıldı. Üçüncü romanı Sârâ, 1926'da yayımlandı. Ayarı Bozuklar romanı da 1926'da tefrika edildi. Yazarın eski harflerle tefrika edilen son romanı Endam Aynası, 1927-1928 tarihleri arasında yayımlandı. Selâhattin Enis'in 19121923 döneminde yazdığı 13 hikâyesi, Bataklık Çiçeği adı altında 1926'da yayımlandı. 1931'de Yürüyüş dergisinde "Bir Gece Faciası" isimli öyküsü yayımlanan Selâhattin Enis 1937'ye kadar edebiyat ortamından uzaklaşır. 1937'de Son Posta mecmuasında 20 öyküsü yayımlanır. Yazar, 1938'de Son Posta'da yalnızca öyküler kaleme alır. 1942 yılında "Korkunç Bir Gecenin Hikâyesi” Son Posta'daki tek yazısıdır. Aynı sene 4 Mayıs’ta Yedigün mecmuasında yayımlanan “Sönen Bir Güneş” adındaki öykü ise yazarın son yazısıdır. (Tane 2012: 23-39).

\section{Amaç}

Bu araştırmanın amacı, Türk edebiyatının önemli isimlerinden Selâhattin Enis’in öykülerinde yer alan kadınlara yazarın yaklaşımı, kadınların sosyal sınıfları, meslekleri, öyküdeki sonları, kadınların tasviri ve aile yapıları bakımından inceleyerek öyküleri değerlendirmektir.

\section{Kapsam ve sinırlılık}

Bu çalışma, Selâhattin Enis’in Bataklık Çiçeği (Enis 2018) isimli öykü kitabında yer alan 13 öykü ile sınırlandırılmıştır.

\section{Selâhattin Enis'in öykülerinde kadın}

Selâhattin Enis, öykülerinde ağırlıklı olarak "İstanbul sosyetesinde cereyan eden sefahat ve fuhşu açık, sert ve hırpalayıcı bir üslupla ele alır (İslam 2005: 326). Batılılaşmanın yanlış anlaşılıp uygulanması ve

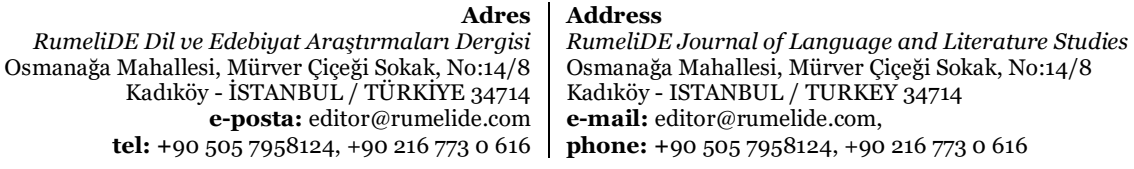


zararları üzerine yazılmış bir öykü toplamı olarak değerlendirilen (Çalışkan 2018: 393) Selâhattin Enis’in Bataklık Çiçeği’nde kadınlar "hep kötü”dür. Hacer Selçuk’un Türk romanı için ifade ettiği "Kötülük Türk romanında genelde yazarın ileteceği mesaj çerçevesinde yararlı ve didaktik işlev yüklenen bir unsurdur. Kötüler daima bütün olumsuz yanlarıyla verilirler. Acımasız, ahlâksız vb. Derinleştirme ve anlama söz konusu olmaz. Kahramanlar çoğu kez ya beyazdır ya siyah, onların gri alanlarda dolaşmasına pek izin verilmez" tespiti (Selçuk, 2019: 77), Enis’in öyküleri için de birebir söylenebilir. Enis’in öykülerinde kadın karakterler net bir biçimde "kötülüklerin anası" yaklaşımıyla yer alır. Ürün Şen Sönmez, "Türk Romanında Kötülük" isimli çalışmasında kötülüğü "birey temelinde", "sosyal temelde" ve "siyasî temelde" kötülük olarak sinıflar (Sönmez, 2012: 86). Sönmez'in bu sinıflaması Selahattin Enis öyküleri temelinde değerlendirilecek olursa; kadınlar önce bireysel, sonra da sosyal temelde kötülüklerin sebebidirler.

\section{Selahattin Enis’in "Bataklık Çiçeği” eserindeki öykülerin incelenmesi}

Öykü: "Bataklık Çiçeği”. "Bataklık Çiçeği” yazar tarafından kitap baskıya girerken, hükümetten habersiz, kitaba dâhil edilmesiyle basılabilmiştir (Başkut, 1942: 56).

Konu: Bu öykü, iyi yürekli bir gençle bir hayat kadınının ilişkisini ele alır. Öyküde gencin adı verilmez.

Kadın karakter: Kadının adı Semra'dır. Semra, yazarın öykülerindeki "kötü kadın” tiplemesinin bir prototipidir.

Özet: Semra'nın babası sürekli alkol alan vurdumduymaz bir baba, annesi ise hasta ve çaresiz bir kadındır. Genç, Semra'ya âşıktır. Onu bataklıktan kurtarıp evine alır ve evlenirler. Gencin aşkı, Semra'nın geçmişini affedecek ve unutacak kadar büyüktür. Kocasına göre İstanbul'un en güzel kadını olan Semra, doymak bilmeyen şehvet duygusuyla, gençle evlendikten sonra da, geçmişindeki ilişkilerini devam ettirir. Eşini aldatır. Gencin kardeşi ciğerlerinden hastadır. Genç, kardeşine yardımcı olmak ve ona bakmak için kardeşini evine alır. Kardeşi Semra ile birlik olup genci sarhoş eder. Genç, olacakların farkındadır. Bir süre sonra Semra'yı kardeşiyle birlikte olurken görür. Genç, Semra'yı o an öldürmeyi aklından geçirse de onu öldürmez.

Kadın tasviri: "Bataklık Çiçeği”ndeki kadın tasvirlerinde ağırlık göz ve dudaklardadır. Semra'nın fiziksel özelliklerinden en çok gözlere değinilir. Genç, tüm hıncını kendisini kasıp kavuran gözlerden almak ister. Kadının güzelliği gözleri ve dudakları üzerinden verilir: Semra'nın fiziki özellikleri öyküde şu şekilde anlatılır:

Uzun ve kuvrcık kirpiklerin arasında ruhu ifsad ve tesmîm eden bu gözler, bütün hayatıma hakim olmuş, bütün sinirlerime tahakküm etmişti. Kaç kereler bu gözlere lanet ettim. Kaç kereler bu gözlerin kör ve alîl olmasın istedim.

Öyle şeytanî gözlerin vardı ki bütün itikatlar üzerine bir kartal kanadı gibi çöküyor, bütün tasavvurlar üstüne bir aslan pençesi gibi yapışıyordu (Enis 2012: 12-13).

Ve gözlerin, uzun ve kıvırcık kirpiklerinle karışmış iki derin ölüm menbaı halindeydi (Enis 2012: 15).

Öyküdeki kadın (Semra), kötülüklerin kaynağı olarak gösterilir: "Seni kötü yapan muhitin değildi. Sen bizzat muzır olmak için adi ve faziletsiz olmak için yaratılmıştın” (Enis 2012: 12).

Semra, alt sosyal sınıftan gelen bir kadındır: "Sarhoş baban senin ilk varlık çekirdeğini ispirtodan almış, hasta anan seni kokuşmuş ve mayalanmış bir kanla beslemişti." (Enis 2012: 12).

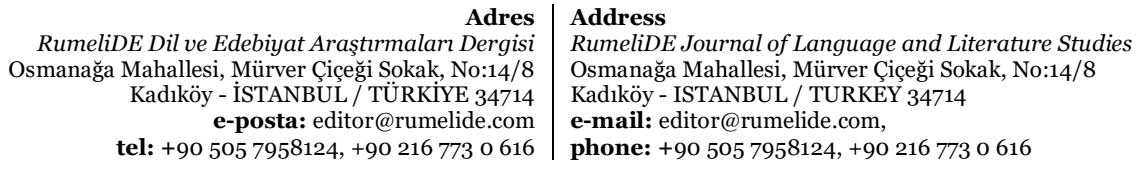


Öykü: "Bir Kadının Son Mektubu”. 1914 yılı "Nevsâl-i Millı̀'de yayımlanan bu öykü aşırı açık-saçı olması nedeniyle döneminde tüm dikkatleri üzerine çeker" (Kudret 1981: 223).

Konu: Öykü, bir hastane köşesinde adı anılmayan bir hayat kadınının ismi bilinmeyen bir dostuna yazığı mektuptan oluşur. Bu öykünün, Enis’in pek çok öyküsünde olduğu gibi, olay örgüsü bireyin toplumla olan mücadelesi üzerine kuruludur.

Kadın karakter: Bu öykünün kahramanı olan hayat kadını, Enis’in diğer öykü karakterlerinden toplumun acımasızlığına karşı direnmesi bağlamında ayrılır. Kadın, içine düştüğü bataklıktan toplumu ve onun değer yargılarını sorumlu tutar: "Ben iyi bir kızdım. Ben çok iyi bir kızdım. Beni kötü yapan, beni adi yapan siz oldunuz." (Enis 2018: 25). İçinde bulunduğu fuhuş ortamının intikamını toplumdan almayı kendine en büyük amaç edinir. Bu öyküde ahlaksızlık, fuhuş, toplumsal yozlaşma ve zenginlerin fakir insanları sömürüşü karşısında isyan eden, öfke duyan ve vicdan azabı çeken bir Selâhattin Enis vardır (Tane 2012: 76).

Öyküdeki kadın, "Bataklık Çiçeği”ndeki Semra gibi toplumun alt katmanından seçilmiştir: "Ben sarhoş bir babayla, fahişe bir ananın soyundan gelmiş ve habislik kötülükler dolu bir muhit içinde büyümüş küçük ve iyi bir kızdım" (Enis 2018: 20).

Kadın tasviri: Anlatıcı kadın kendi güzelliğini, fiziksel tasvirini şöyle yapar: “... benim güzel bir çehrem, yumuşak bir cildim ne nefis bir vücudum vardı” (Enis 2018: 20).

Öykü kadın karakterin bir hastane köşesinde yapayalnız ve içinde yaşadı̆̆ı topluma nefret eder halde kalmasiyla son bulur.

Öykü: “İmamın Fatma Hanım”.

Konu/özet: Fatma Hanım'ın Maviş adındaki kedisi bir gün hastalanır ve onu iyileştirmeye çalışan sahibesinin üstüne atılır. Bu olaydan birkaç gün sonra Fatma Hanım ölür. Kedi kudurarak, Fatma Hanım da kuduz olarak ölür.

Kadın karakter: İmamın Fatma Hanım, mahallesinde kedileriyle özdeşleşen, onları besleyip onlara sahip çıkan ve kocasının ölümünden sonra tüm sevgi ve ilgisini kedilerine gösteren bir kadındır. Fatma Hanım, yazarın öykülerinde anlattığı birkaç “iyi kadın”dan biridir. İyi yürekli, sevecendir.

Kadın tasviri: Öyküde Fatma Hanım'ın fiziki tasvirine yer verilmez. Fatma Hanım, orta sınıf bir ailenin hayatını yaşar. Ne muhtaçlık derecesinde yoksul, ne de zengin denilebilecek kadar varsıldır.

\section{Öykü: "Lambo Usta”}

Konu/özet: Lambo Usta, Karamanlı bir Rum'dur. İstanbul'a gelip iç mahallelerin birinde bir bakkal dükkânı açar. Çok sevmediği karısını İstanbul'a getirmez. "O halde terlediği zaman yağlı bir pastırma gibi kokan karısını bir heybe gibi taşımaya ne lüzum vardı?” (Enis 2018: 36). İşleri yoluna koyan Lambo Usta, karısını getirmediğine pişman olur. Bir süre sonra kendine bir gönül arkadaşı arayışına girer. Mahallerine henüz taşınan yeni hariciye kalemi kâtiplerinden Necip Fehmi Beyin hizmetçisi Anika'yı takibe alır ve bir süre sonra ona âşık olur. Anika, Lambo Usta'nın kendisine olan aşkından faydalanmak ister. “Anika, Lambo Usta'nın kendisine tutkun olduğunu biliyordu. Onu tam burnundan yakalamıştı. ... kasten eliyle yahut koluyla ona temas ediyor, onu çldırtıyordu. ...Anika kendini dirhem dirhem

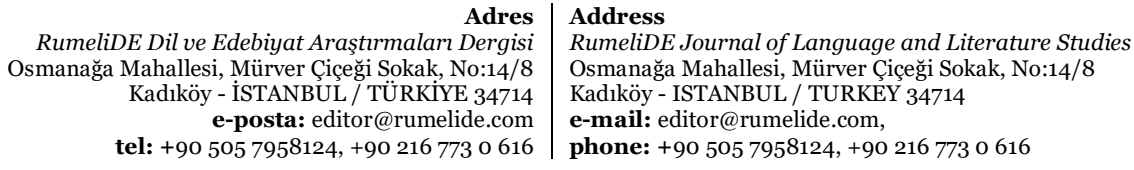


satıyor, bu sohbetleri en lezzetli yerinde bırakarak eve geç kaldığını söyleyip dükkânı terk ediyordu" (Enis 2018: 42).

Kadın karakter: Anika. Enis'in bu öyküsünde de kadın yine karşımıza bir kötülük, bir fitne unsuru olarak çıkar. Mahalledeki tek bakkal Rakibi Mihal'i dahi alt eden Lambo Usta, genç bir aşüfte (Anika) karşısında yenilir ve elde edemediği bu genç aşüfte yüzünden yıllarca uğraşıp kurduğu ticarethane iflas eder. Erkeklerin en büyük zaafı olan kadınların, erkeklerin hayatlarını nasıl alt üst edebileceklerinin anlatıldığı Lambo Usta yazarın samimi ve gerçeğe çok yakın bir hikâyesidir (Tane; 2012: 100).

Kadın tasviri: Öyküde Lambo Usta'nın karısının fiziki tasviri; "göğsünden iki tulum gibi sarkan memeleriyle iri yapılı bir ineğe benzeyen... kaba, çopur, pis ve çirkin” (Enis 2018: 40) şeklinde verilir.

Öyküdeki kadın karakterler (Anika ve Lambo Usta’nın karısı), toplumun alt sınıfından seçilmiştir.

Öykü: "İsyan”.

Konu/özet: Yoksul bir ressamın, karısının hastalı̆̆ı karşısında, maddi imkânsızlıklardan dolayı çaresizliğinin anlatıldığı öykü, mektup şeklindedir.

Kadın karakter: Enis'in "habis, kötü, fahişe, aşüfte" olarak öykülerinde yer verdiği kadınlara bu öyküde rastlanılmaz. Ressamın annesi de karısı da oldukça iyi ve güzel insanlar olarak anlatılır: "Yaşadığımız hayatın elem verici sefilliğine rağmen karım kendini mesut ve bahtiyar gösteriyordu" (Enis 2018: 84). Ressamın karısı her türlü yoklukta ve kötü günde eşinin yanında olur. Ne ona ne de kendi iyi yürekliliğine ihanet eder. Bir gün dahi yoksulluktan şikâyet etmez. Amansız hastalık anında bile eşine güzel bakar.

Kadın tasviri: Gözler, bu öyküde de Enis’in güzellik anlatımının merkezindedir. Karısının bu şefkati, iyiliği, hatta gözlerindeki güzelliği adama annesini hatırlatır: "Onun, karımın gözleri de senin gözlerine benziyordu" (Enis 2018: 53). Karısının hastalı̆̆ı ve üşümesi karşısında sokaklarda çaresizce dolanan adam en son karısı üşümesin diye yaptığı bir tabloyu yakar ama eşi üşüyerek ölür.

Öykü: "Bağırsak".

Konu/özet: Yazar bu öyküsünde genelevlerine karşı olan nefretini açıkça belli eder. Beyoğlu, İstanbul'un bağırsaklarına benzetilir. Randevuevleri anlatıcı kahraman üzerinden öfkeli bir dille anlatılır. Anlatıcı-kahraman bir gece Beyoğlu'na çıkar. Beyoğlu'nu ve Beyoğlu sokaklarını yılların verdiği tecrübeyle çok iyi tanır. Beyoğlu sokakları insanların bütün "içtimai kisvelerinden tamamen arınarak" girdikleri sokaklardır. Bu sokaklar insanları her türlü sosyal sıfatlarından sıyırırlar, maskelerini indirirler. Bu sokaklarda ar, hayâ, edep, ahlak denen şey yoktur.

Kadın karakter: Genelevde çalışan kadınlar. Bu kadınlar öyküde aşă̆ılanır ve kötülenir:

...zirâ bu kadınlar hakiki birer inektirler. Suratları ebleh ve ahmaktır. Her gece ve her saat için uykusuzluk, cima, ispirto bu kadınlardaki bütün aklî melekeleri tahrib etmiş, onları hakiki birer ahmak haline getirmiştir... Mefkûreleri basit, çehreleri ebleh olan bu kadınlarm hassasiyetleri de iptidaîdir. Kalpleri hiçbir şey duymaz, hakiki bir kaldırım taşı gibidir. Onlar sevmeği bilmezler, sevilmekten anlamazlar, bir hayvan gibi yalnız paraya tapınılar, yalnız para derler. Paraya olan bu merbutiyetleri niçindir? Eminim ki bu kadınların hiçbirisi hayatında bu 'niçin’i halledememiştir. Bu paraya gayr-ı idrakî bir tapınıştır. (Enis 2018: 63)

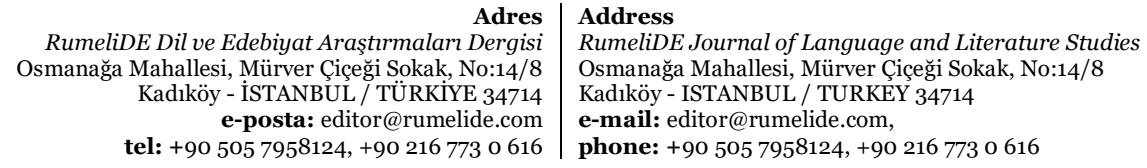


Selâhattin Enis öykülerindeki anlatıcılar, sokaktaki hayat kadınlarını aşağılamanın yanı sıra onlara şiddet uygulanması gerektiğini de söyler: “...öptüğünüz zaman köpek gibi ısırmalı, okşadığınız zaman bacakları çimdiklerinizle çürümeli, kıçları tokatlarınızla kızarmalı, sırtına indirdiğiniz yumruklarla ciğeri sökülürcesine sarsılmalı...” (Enis 2018: 63-64).

Öykü: "Şaheser".

Konu/özet: Öyküde, idam cezasına çaptırılan bir gencin hikâyesi anlatılır. Gencin adı verilmez, ondan sadece "bu adam”, "bu mahkûm”, "bir genç", "bu mücrim” gibi genel ifadelerle söz edilir. Genç, alkolik bir babanın, evini geçindirmek için kötü yola düşen bir annenin evladıdır. Babası adi bir suçtan idam edilir. Annesi genci evden kovar ve hayat kadınlı̆̆ına devam eder. Genç, hırsızlığa başlar. Hayata ve annesine olan intikamını Roza adındaki bir hayat kadınından alır. Kazandığı her parayı o kadına sahip olmak için onun avuçlarına bırakır. İdamlık genç zengin ailelerden birinin yaşadığı bir eve girip hırsızlık yapar, çıkarken evi de ateşe verir. Sonra doğruca Roza'nın yanına gider. Çaldığı paraları önüne atar. Önceleri para para diye tutturan Roza paraları görünce gencin karşısında bir "köpek" kadar küçülür. Roza'yı göğsünden bıçaklar. Artık Roza'yı doyurmuştur. Pencereye gelir, biraz önce çıkardığı yangını ve Roza'nın yerde yatan ölüsünü, iki şaheserini seyreder. Bütün vücudu frengi içinde her türlü cezaya razı, gururla ölüme giderken kendisini yargılayan hâkime teşekkür ve dua eder. Öykü, idama mahkûm edilen gencin savunmasından oluşur. Genç, savunmasında onu idama götüren süreci anlatır.

Kadın karakter: Yazarın öykülerinde tek yabancı hayat kadını bu öyküdeki idamlık gencin aşık olduğu Roza'dır (Tane 2012: 83-84).

Kadın tasviri: Anlatıcı, Roza’yı "adi bir mahlûk" olarak gösterir: "Ben işte bu kadının göz ve dudaklarında ruhumun zevk ve arzularını buluyordum. Ve paradan yapılmış adi bir mahlûk olmasına rağmen onu seviyordum" (Enis 2018: 73-74).

Selâhattin Enis, romanlarında olduğu ve görüldüğü gibi "Sanatçının romanlarındaki aslî kadın şahıslar iffetsiz, doyumsuz, yozlaşmış, aile kadını vasfından uzak kadınlardır”( Ecevit 2019: 414) öykülerinde de ağırlıklı olarak kadınlara karşı olumsuz ve kötü bakış açısına sahiptir. Bu yaklaşımı bu öyküde de görmek mümkündür. Öyküdeki genç, kadınlara bakışını şu sözlerle anlatır: Kadın ve yemek!.. Ah, bunlar iki şeytandır Reis Beyefendi. Hüviyetinizi tırnaklayan, birine verdikçe diğeri 'Bana da!..' diye başını çıkaran ve somurtan iki melun şeytandır" (Enis 2018: 70).

Öykü: "Bütün Bir Hayat”.

Konu/özet: Bu öyküde de bir âşık ve tecrübesiz bir gencin hayatını mahveden bir hayat kadını vardır. Ahmet Mualla adındaki genç, Nazan isimli bir hayat kadınına âşık olur. Ailesinden miras kalan zenginliği başta Nazan ve Semra olmak üzere hayat kadınlarına yediren Ahmet Mualla, sonunda parasız kalır. Bir kahvede çok düşük bir paraya çaycılık yapar. Her şeye rağmen Nazan'a âşıktır. Nazan'ın evinde zengin erkeklerle yaşadıkları Ahmet Mualla'yı çok rahatsız eder. Ancak onun yapacak bir şeyi kalmamıştır. Hem parasız hem itibarsız kalmıştır. Öykü, Ahmet Mualla’nın Nazan’a bir gün onu bileklerini keserek öldürebileceği veya evini ateşe verebileceği tehdidiyle sona erer.

Kadın karakter: Gencin âşı olduğu Nazan ve Ahmet Mualla'nın metresi olan Semra. Nazan, varlıklı bir hayat kadınıdır. Zengin müşteriler onunla birlikte olmak için sıraya girer. Semra ise Nazan kadar varlıklı değil, en alt sınıftan bir kadındır.

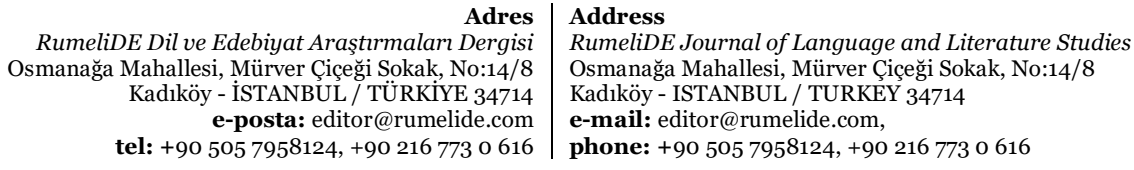


Kadın tasviri: Nazan’ın fiziki tasviri “güzel gözlü hanımefendi” şeklinde yapılırken gencin metresi olan Semra “...bu kadın şu vücuduyla, şu düzgün vücuduyla hiçbir vakitte ruhun kadını olamazdı. Hatta onun şu yatışında bile iyi bir kadının teslimiyet duruşu yoktu. Bilakis herkesin altına yatak gibi serilen bitkin ve yorgun bir orospunun iğrenç haraplı̆̆ vardı” (Enis 2018: 80) ifadeleriyle anlatılır.

Öykü: "Kurtlar".

Konu/özet: Yazar bu öyküsünde insanın tabiatla olan mücadelesi anlatılır. Bir kış günü jandarmalar Fatma'nın kocasını asker kaçağı olduğu iddiasıyla alıp götürürler. Fatma yalnız kalır. Kış en yoğun biçimde kendini hissettirir. Bir gece Fatma'nın evini kurtlar basar. Fatma kurtlarla mücadele eder. İkisini öldürür. Köylüler sabah Fatma'nın evine geldiklerinde kurtların leşiyle ve Fatma'nın ödü patlamış şekilde ölüsüyle karşılaşırlar.

Kadın karakter: Çıtak isimli bir köyden başka bir köye gelin gelen Fatma.

Öykü: “Avdet”.

Konu/özet: Yazar bu öyküsünde savaştan dönen kahramanın karısını ve tanıdıklarını araması anlatılır. Adam, hiç kimseyi bıraktı̆̆ı yerde bulamaz. Karısına da ulaşamaz. Kahraman, sarhoş bir halde sokakta gezinirken hayat kadını olan karısıyla karşılaşır ve onu takip eder. Kötü yola düşen karısını yaşadığı lüks apartmanın mermer basamaklarına firlatarak öldürür.

Kadın karakter: Kahramanın kötü yola düşen karısı. Öyküde kadının fiziki tasviri yapılmaz.

Öykü: "Hufre"

Konu/özet: Bu öyküde belirgin bir olay, yoktur. Hikâye, kadın cinsel organının hufre (delik) biçiminde sembolize edilmesi üzerine kurulmuştur.

Kadın karakter: Öyküde kadınlar genel olarak kötülenir. Kadınlık duyguları aşağılanır.

Kadın tasvirleri: Kadınları aşağılayııı nitelemeler öyküde zirve yapar: “... kadın, tabiatın beşeriyete musallat ettiği en korkunç bir veba, en yıkıcı bir kasırga, en muazzam bir afettir... Eğer vücudunuz ılık olmasaydı ve vücudunuzda daha sıcak zevk ve hayat noktaları bulunmasaydı siz bizim için mermer bir heykelden daha kıymetli mi olurdunuz?” (Enis 2018:106).

"Hufre"deki kadına yaklaşım biçimi büyük tepki toplar. Enis, bu öyküsünde kadınları aşağıladığı iddiasıyla çokça eleştirilir. Bu eleştirilere karşı yazar "rakiplerinin bu ağır sözleri sanki bütün kadınlara söylediğini iddia ettiklerini, bunu da iğrenç bir yalan olduğunu” ifade ederek, namusu her şeyin üstünde tutan bir insan olduğunu belirtir ve namuslu kadınlara asla hücum etmediğini söyler (Enis, 1337: 1-2).

"Hufre" bir durum hikâyesi olarak nitelendirilebilir. Anlatıcı-kahraman güzelliğiyle herkesi cezbeden bir kadına üç aydan beri âşıktır. Üç ayın sonunda anlar ki bu aşk bütün beşerin aşkları gibi hayvani bir eğilimden başka bir şey değildir. Anlatıı-kahraman üç ay sonra birtakım şeylerin daha farkına varır: Kadın tabiatın en tehlikeli varlığıdır. Kadınlar olmasaydı bugün insanlığın çektiği sıkıntıların hiçbiri olmayacaktı. Selâhattin Enis’in hikâyeleri arasında kadının "çirkin”, "kötü” biçimde ele alındığı hikâyesi "Hufre"dir. "... ekser mevzularını hayatın en pis ve iğrenç noktalarında taharri eden" Selâhattin Enis (Aslan 2003) bu hikâyede kadını sadece bir "hufre (delik)"den ibaret görür. Anlatıcı-kahramanın

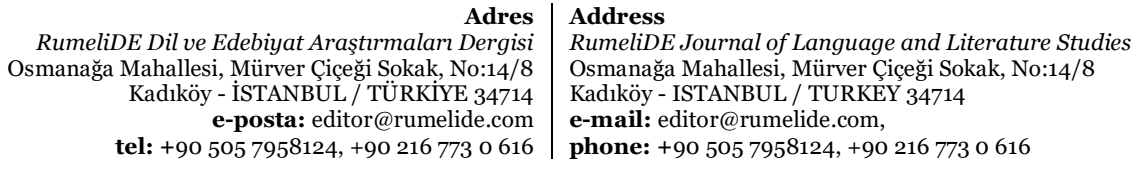


ifadelerine göre kadın "tabiatın beşeriyete musallat ettiği en muhavvel bir veba ve en yakıcı bir kasırga, en muazzam bir afettir.” Yeryüzünde bütün kavgaların, bütün savaşların tek nedeni kadınlardır. Kadınların asıl gücü taşıdıkları uzviyet (hufre) ve şehvetten kaynaklanır (Tane 2014: 92).

\section{Sonuç}

Bataklk Çiçeği’nde 13 öykü yer almaktadır. "Çingeneler" ve "Teşrihhanede" öykülerinde kadın karakterler yoktur. Diğer 11 öyküdeki kadın karakterler incelenmiştir. Öyküler; kadınlara yaklaşım, kadınların sosyal sınıfları, meslekleri, öyküdeki sonları, kadınların tasviri ve aile yapıları bakımından incelenmiş ve şu sonuçlara ulaşılmıştır:

Kadınlara yaklaşım bakımından öyküler: Selâhattin Enis’in incelenen öykülerinde kadın kahramanlara dair en önemli husus kadınların bir kötülük kaynağı olarak görülmesi, tahkir edilmesi ve kadınlara karşı olumsuz bakış açısının dikkat çekmesidir. "Hufre" kadını ve kadınlığı tahkir etmede en çok dikkat çeken öyküdür.

Kadınların sosyal sınıfları açısından öyküler: Selâhattin Enis’in öykülerindeki kadınlar ağırlıklı olarak sosyoekonomik açıdan en alt katmanda yer alan kişilerden seçilmiştir. "Bataklık Çiçeği”ndeki Semra, ”Bir Kadının Son Mektubu”ndaki isimsiz kadın, "Lambo Usta”daki Anika, “İsyan”daki isimsiz ev hanımı kadın, "Şaheser”deki Roza, "Bütün Bir Hayat”ta Semra ve "Avdet”teki savaştan dönen adamın karısı, bu karakterlerden bazılarıdır. Öykülerdeki tek varlıklı kadın olan "Bütün Bir Hayat”taki Nazan da aslen alt sosyal sinıftandır ancak sonradan zengin olur.

Kadınların meslekleri açısından öyküler: Ev hanımı olanlar: Fatma Hanım, "İmamın Fatma Hanım", Lambo Usta'nın ismi verilmeyen karısı, "Lambo Usta” ve ressamın adı verilmeyen karısı, "İsyan"; kocası asker kaçağı olan Fatma, "Kurtlar". Hizmetçi Anika, ”Lambo Usta”; dışında kalanlar da hayat kadınıdır: Semra, "Bataklık Çiçeği”; ismi verilmeyen kadın, "Bir Kadının Son Mektubu"; Roza, "Şaheser”; Semra ve Nazan, "Bütün Bir Hayat”; savaştan dönen adamın ismi verilmeyen karısı, ”Avdet”.

Kadınların sonu açısından öyküler: Öykülerdeki kadınların sonu ya kendi kaderlerine terk, "Bataklık Çiçeği”; "Lambo Usta”; "Bütün Bir Hayat”; "Bir Kadının Son Mektubu”, öldürülme, ”Şaheser”; "Avdet”; "Kurtlar” veya hastalıktan ölme, "İsyan”; "İmamın Fatma Hanım” şeklindedir.

Kadın tasvirleri bakımından öyküler: Selâhattin Enis’in öykülerinde kadınların fiziki tasvirlerinde en çok gözler yer alır. Gözler ve dudaklar kadınların "güzellik" nitelemesinde tüm öykülerde vardır. İncelenen öykülerde güzel kadınlar, bu güzelliklerini insanların hayatlarını mahvetmek için kullanırlar. Fiziki anlamda "çirkin" olarak tasvir edilen iki kadından biri "Lambo Usta” öyküsünde Lambo Usta'nın köyünde bıraktığı karısı, diğeriyse "Bütün Bir Hayat”taki Semra’dır.

Kadınların aileleri bakımından öyküler: Öykülerde kadınların aile bilgilerine pek yer verilmez. "Bataklık Çiçeği”ndeki Semra'nın babası sarhoş, annesi hasta bir kadın olarak belirtilirken; “Bir Kadının Son Mektubu”ndaki isimsiz hayat kadınının babası sarhoş ve ayyaş, annesi de bir hayat kadını olarak ifade edilir.

Bataklk Çiçeği’ndeki “iyi yürekli kadın” olarak çizilen üç karakter vardır. Bunlar yazarın ender "iyi kadınlar" ındandır. "İmamın Fatma Hanım"daki Fatma Hanım, kocasını yitirdikten sonra tüm ilgi ve sevgisini sokak kedilerine veren bir kadındır. "İsyan”daki ressamın karısı da eşine ve ailesine sadık bir kadındır. "Kurtlar"daki Fatma da eşine sadık, kendi halinde bir kadındır. Bu üç iyi kadının da feci bir

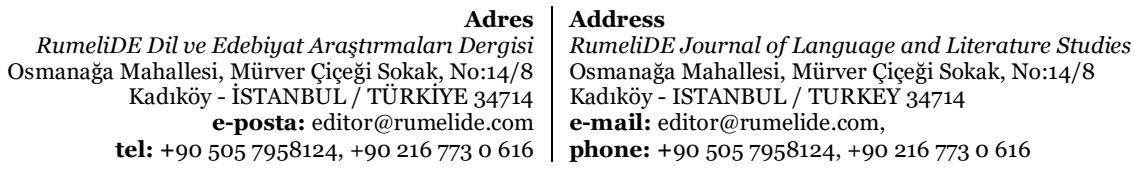


şekilde ölümü (Fatma Hanım, kuduz olur ve ağzından köpükler gelerek ölür; ressamın karısı ise yoksulluk içinde hastalanıp üşüyerek ölür; asker kaçağı adamın karısı olan Fatma evini basan aç kurtlarca öldürülür) yazarın kadın karakterlere çizdiği "kötücül” yaklaşımın bir sonucu olarak görülebilir.

\section{Kaynakça}

Aslan, N.G. (2003). Selâhattin Enis’in Romanlarında Osmanlı İmparatorluğu’nun Son Yillarma Bir Bakış, İstanbul: Dergâh.

Başkut, C. F. (1942). "Selâhattin Enis ile Senelerce Evvel Yapılmış Bir Mülakat”. Servetifünun (Uyanış), (2391), 56 .

Çalışkan, A. (2018). "Ana Çizgileriyle Cumhuriyet Devri Türk Hikâye ve Romanına Teorik Bir Yaklaşım (1923-1939)" Turkish Studies Social Sciences, (13/18), 365-485.

Ecevit, H. (2019). Selâhattin Enis’in Romanlarında Şahıslar Dünyası. (Yayımlanmamış Yüksek Lisans Tezi). Uludağ Üniversitesi Sosyal Bilimler Enstitüsü.

Enis, S. (1337). "Yine O Yara". Payitaht, (52), 1-2.

Enis, S. (2018). Bataklık Çiçeği. İstanbul: Ayrıntı.

İslam, A.K. (2015). Yeni Türk Edebiyatı El Kitabı, Editör Ramazan Korkmaz, Ankara: Grafiker.

Kudret, C. (1981). Türk Edebiyatında Hikâye ve Roman (1859-1959) / Meşrutiyet'ten Cumhuriyet'e Kadar (1911-1922), C. 2, İstanbul: Varlık.

Selçuk, H. (2019). Kötülük estetiği bağlamında edebiyatın üç kötücül kahramanı: Mephistopheles, Lord Henry ve Suat. (Yayımlanmamış Yüksek Lisans Tezi). İstanbul Üniversitesi Sosyal Bilimler Enstitüsü.

Sönmez, Ü. Ş. (2017). Kötülüğün Yerel Temsilleri: Türk Edebiyatında Kötülük. İstanbul: Yapı Kredi.

Tane, V. (2012). Selâhattin Enis Atabeyoğlu'nun hayatı ve eserleri üzerine bir araştırma. (Yayımlanmamış Doktora Tezi). Ege Üniversitesi Sosyal Bilimler Enstitüsü.

Tane, V. (2014). "Selahaddin Enis'in Hikâye ve Romanlarında Kadın Kahramanlar”. SDÜ Fen Edebiyat Fakültesi Sosyal Bilimler Dergisi, (33), 87-108.

RumeliDE Dil ve Edebiyat Araştırmaları Dergisi Osmanağa Mahallesi, Mürver Çiçeği Sokak, No:14/8 Kadıköy - İSTANBUL / TÜRKIYE 34714 e-posta: editor@rumelide.com tel: +90 $5057958124,+902167730616$
Address

RumeliDE Journal of Language and Literature Studies Osmanağa Mahallesi, Mürver Çiçeği Sokak, No:14/8

Kadıköy - ISTANBUL / TURKEY 34714

e-mail: editor@rumelide.com,

phone: +90 5057958124, +90 2167730616 